\title{
Eficiência produtiva da agropecuária do estado de Santa Catarina e seu novo espraiamento territorial pós-2003
}

\author{
Productive efficiency of agropecuaria in the state of Santa Catarina \\ and its new territorial spreading post-2003
}

\author{
Roberto César Costa Cunha'(i), Carlos José Espíndola'(i) \\ ' Universidade Federal de Santa Catarina - UFSC, DEGEO, Florianópolis, SC, BRASIL.
}

\section{RESUMO}

O processo de modernização, pós-1960, transformou a agropecuária catarinense em um ramo especializado da produção inserido na divisão social do trabalho. Nos anos de 1990, os diferentes produtos agrícolas catarinenses (soja, leite, carnes, frutas, madeira, milho, fumo, entre outros) passaram por intenso processo de reestruturação técnica e econômica, agregando alterações geoeconômicas e sociais a jusante e a montante das atividades agropecuárias. Dessa forma, constituem-se hoje em um dos principais setores econômicos geradores de renda no estado. Entre 2003-2020, o valor bruto da produção dos principais produtos agrícolas catarinenses cresceu de $R \$ 11,7$ milhões para $R \$ 28,3$ milhões. Nas exportações, o valor gerado em 2019 foi de US\$ 6,2 bilhões, o que representa 69,6\%, do valor total do estado, e 6,4\%, do valor total dos produtos do campo brasileiros. Desvendar a eficiência produtiva da agropecuária catarinense, com base nos indicadores de área plantada, valor bruto da produção, produtividade e participação na pauta exportadora catarinense, é o objetivo central deste texto. Esse dinamismo veio acompanhado de alterações significativas nas estruturas produtivas regionais. As antigas áreas agrícolas apresentaram transformações na sua estrutura, forma e função, promovendo um novo espraiamento territorial.

Palavras-chave: Eficiência produtiva; Estruturas produtivas mesorregionais; Especialização; Formação socioespacial

\section{ABSTRACT}

The post-1960 modernization process transformed Santa Catarina's agriculture into a specialized branch of production within the social division of labor. In the 1990s, the different Santa Catarina agricultural products (soy, milk, meat, fruit, paper and cellulose, corn, tobacco, among other products), underwent an intense process of technical and economic restructuring, adding geoeconomic and social changes downstream and upstream of agricultural activities. Thus, they are now one of the main incomegenerating economic sectors in the state. Between 2003-2020, the gross production value of the main 
agricultural products from Santa Catarina grew from R \$11.7 million to R \$28.3 million. In exports, the value generated in 2019 was US $\$ 6.2$ billion, which represents $69.6 \%$, of the total value of the state, and $6.4 \%$, of the total value of products from the Brazilian field. To unveil the productive efficiency of Santa Catarina's agriculture, based on the indicators of planted area, gross value of production, productivity and participation in the Santa Catarina export basket, is the central objective of this text. This dynamism was accompanied by significant changes in regional productive structures. The old agricultural areas have undergone transformations in their structure, form and function, promoting a new territorial spread.

Keywords: Productive efficiency; Mesoregional productive structures; Specialization; Socio-spatial formation

\section{INTRODUÇÃO}

A ocupação do território catarinense, a partir do século XVII, resultou na constituição de duas grandes estruturas agrárias. Uma localizada no Planalto e caracterizada, predominantemente, pela pecuária extensiva, e a outra situada nos vales atlânticos e do interior, assentada na produção diversificada de milhares de pequenos produtores mercantis. Em ambas as estruturas, combinavam-se, de forma diferenciada, a agricultura e a pecuária. Em sua trajetória evolutiva, essas estruturas passaram por profundas transformações, sobretudo, a partir de 1960. Tratou-se, com o apoio estatal, da implantação de um novo padrão para a agropecuária catarinense, que se manifestou em novas atividades, tanto a montante como a jusante do seu processo produtivo. Isto é, na emersão, expansão e consolidação de diferentes estruturas agrícolas produtivas, como, por exemplo, de soja, carnes, leite, milho, arroz, fumo, frutas e madeira.

\footnotetext{
${ }^{1}$ Em um processo histórico, a mudança que interessa para o conhecimento é a mudança em relação ao todo. O presente e o futuro não são a meta da história passada. Assim, em uma sociedade capitalista, por ela ser a mais desenvolvida e conter variadas formas de produção, que são mais elaboradas, ela nos permite mostrar certas características de sociedades passadas, como resíduos e vestígios ainda presentes (CUNHA, 2020). Dessa forma, no texto optou-se pela agropecuária (lavouras e criações), pois se caracterizou por significativa especialização e diferenciação mesorregional, com diversos territórios produtivos dominados pelas culturas de grãos e por rebanhos que outrora não exerciam essas funções. As abordagens territoriais são necessárias, pois "o complexo produtivo da agricultura desenvolveu-se com a formação de inúmeros segmentos produtivos com estruturas produtivas para mais além dos limites da agropecuária, rompendo com a concepção rural ao formar cadeias de produção que não mais se explicam pela dicotomia campo-cidade. Nesse processo, em que cada vez mais a produção passou a ser cada vez menos 'fruto da terra e do trabalho do homem', na acepção bíblica cristã, não apenas o trabalho foi potencializado e perdeu espaço para a mecanização e
} 
Em 2020, o valor bruto da produção (VBP)² produzido pela agropecuária foi de $\mathrm{R} \$ 28,3$ bilhões, o que representa $30 \%$ do Produto Interno Bruto (PIB) catarinense (BRASIL, 2021a). Desse total, enquanto R $\$ 17,9$ bilhões correspondem à pecuária, R\$10,3 bilhões, às lavouras. Entre 2003-2020, a agropecuária catarinense passou de $R \$ 11,7$ bilhões para $R \$ 28,3$ bilhões, o que representa um crescimento da ordem de 2,4 vezes. Nas exportações, em 2019, o valor gerado pelos produtos agrícolas catarinenses foi de US\$ 6,2 bilhões (BRASIL, 2021a), o que se refere a $69,6 \%$ do valor total das exportações do estado e $6,4 \%$ do total das vendas externas dos bens produzidos pela agropecuária brasileira (BRASIL, 2021b).

Diante do dinamismo e da representatividade da agropecuária catarinense, este texto tem como objetivo desvendar a eficiência produtiva agrícola catarinense e o novo espraiamento ocorrido nas estruturas mesorregionais de produção pós-

automação, mas também a terra perdeu espaço para a fertilização, correção e genética, que impulsionaram a produtividade da terra. A agropecuária moderna pode ser feita com menos terra e menos trabalho, mas com muito mais capital, estando inserida na lógica de expansão da reprodução ampliada do capital. O complexo da agropecuária pode ser visualizado como uma estrutura de segmentos setoriais na qual a produção biológica passa a ser veículo estratégico para a combinação de insumos e instrumentos gerados fora dos campos e a ser fornecedora de bens intermediários para estruturas de agregação de valor, envolvendo empreendimentos em cadeias que se iniciam nas fábricas de insumos e maquinaria e finalizam-se nas estruturas de varejo" (GONÇALVES, 2005, p. 1011). Ver detalhes sobre esse complexo produtivo da agricultura em Espíndola e Cunha (2020). Por esse motivo, justifica-se a escolha metodológica pelo fato de que na agropecuária moderna a quantidade produzida e o VBP são métricas essenciais para o modelamento de territórios.

2 É a expressão monetária da soma de todos os bens e serviços produzidos em determinado território econômico, num dado período de tempo. O VBP agropecuário representa uma estimativa da geração de renda do meio rural, revertendo em uma variável relevante para acompanhamento do desempenho do setor na sua íntegra. O VBP agropecuário mostra a evolução do desempenho das lavouras e da pecuária ao longo do ano e corresponde ao faturamento bruto dentro do estabelecimento; é calculado com base na produção da safra agrícola e da pecuária, e nos preços recebidos pelos produtores nas principais praças do país, dos 26 maiores produtos agropecuários do Brasil (CUNHA; ESPÍNDOLA, 2020). A estimativa do VBP é elaborada pela Coordenação-Geral de Estudos e Análises (CGEA), do Departamento de Crédito e Estudos Econômicos (DCEE), da Secretaria de Política Agrícola (SPA), do Ministério da Agricultura, Pecuária e Abastecimento (MAPA) (BRASIL, 2018). No entanto, Faria (1983, p. 109-110) assinala que esse agregado macroeconômico pode trazer distorções, como a dupla contagem, por exemplo. Diante disso, elaborou-se o "conceito de Valor Adicionado Bruto (VAB), que é utilizado como medida da riqueza social gerada em uma região ou país em determinado período. A definição do VAB é dada pela diferença entre o VBP e o consumo intermediário $(\mathrm{Cl})$. Isto é, o valor de todas as mercadorias que entram na produção de outras mercadorias é descontado do valor total das mercadorias produzidas". No texto, optou-se em utilizar VBP para o Brasil e para o estado de Santa Catarina, e VAB para as mesorregiões do estado para minimização das distorções regionais. 
4 | Eficiência produtiva da agropecuária do estado de Santa Catarina e seu novo espraiamento territorial pós-2003

2003. Justifica-se a escolha do período em virtude de a economia brasileira ter vivido, entre 2003-2019, dois momentos distintos. Enquanto entre 2003-2011 o crescimento do PIB foi em média de 3,9\%, entre 2011-2019, caminhou para uma queda, resultando em taxa média de crescimento de 0,5\%. Em termos per capita, entre 2003-2010, o PIB cresceu duas vezes, passando de $R \$ 9,5$ mil para $R \$ 19,9$ mil. Já, entre 2010-2017, cresceu uma vez e meia (CUNHA, 2020)33. Mediante intenção de alcançar tal objetivo, utilizou-se a categoria formação socioespacial ${ }^{4}$ elaborada por Santos (1977), bem como a abordagem das combinações geográficas de Cholley $(1964)^{5}$. Segundo Santos (1977), uma formação socioespacial é uma realidade concreta, que se transforma, evolui e

\footnotetext{
${ }^{3}$ Segundo Cunha (2020, p. 117-118), "o primeiro período, 2003-2011, foi sustentado por medidas político-institucionais implantadas, como a ampliação do crédito ao consumidor, política de transferência de renda, política de valorização do salário-mínimo, medidas de ampliação dos programas sociais, política de estímulos aos investimentos públicos e privados, políticas de estímulos ao comércio exterior, entre outras. O resultado final foi uma onda de investimentos assentados em três frentes: infraestrutura; recursos naturais; e consumo de massa. Contribuíram ainda para o ciclo expansivo a liquidez financeira mundial, os investimentos externos diretos (IED) e a elevada demanda mundial de commodities. No segundo período entre 2011-2016, a política econômica adotada foi marcada por dois direcionamentos. O primeiro, entre 2011-2014, foi assentado na chamada "Nova Matriz Econômica", que buscou implantar a redução de taxas de juros, a redução de tarifas públicas, as desonerações fiscais, a ampliação do crédito, a desvalorização cambial e o incentivo as parcerias público-privadas. O segundo direcionamento da política econômica, pós-2014, combinava políticas contracionistas, com elevação da taxa de juros e redução do crédito ao consumidor com políticas de desonerações fiscais, entre outras". Ver mais em Bielschowsky (2013); Barbosa (2013) e Espíndola (2016c).

${ }^{4} \mathrm{O}$ interesse do texto é recuperar a categoria formação socioespacial como possibilidade de ser um mecanismo eficiente para interpretar a realidade da agropecuária do Brasil e de suas regiões.

${ }^{5}$ Conforme Cholley (1964), essas combinações podem ser de três tipos: (i) aquelas que convergem de fatores físicos (a geomorfologia, a hidrologia, etc.); (ii) as de complexidade maior de ordem física e de ordem biológica (o cerrado); e (iii) as de ordem tridimensional, mais complexas e muito mais requintadas de detalhes, de ordens físicas, biológicas e humanas (agricultura, indústria, comércio). Essas combinações geográficas ampliam as possibilidades das análises, pois a realidade é fruto das relações contraditórias entre os aspectos naturais e humanos. Essas relações são estabelecidas em múltiplas escalas (mundial, nacional, regional e local) e permitem compreender um determinado objeto de estudo num universo mais amplo. Para uma combinação ser originalmente geográfica, é necessário que ela interfira na totalidade de um grupo humano, pois o caráter geográfico é determinado pela relação espaço e tempo. Um determinado sistema agrícola é composto por combinações geográficas mais complexas, pois resultam da interação de elementos físicos (solo, clima, etc.), elementos biológicos (flora) e elementos humanos (máquinas e mão de obra). Assim, o homem, para escolher um determinado cultivo e as técnicas mais adequadas, tem de observar as condições naturais que o cercam para obter as colheitas necessárias à sua sobrevivência.
} 
muda com o processo histórico. Trata-se de uma categoria das totalidades históricas que deve ser considerada como expressão socioespacial dos processos que se singularizam em virtude de determinadas combinações. Assim, cada formação socioespacial é singular, na qual os processos gerais interagem com as características particulares, gerando combinações geográficas específicas.

Com isso, as estruturas técnicas e produtivas se expressam geograficamente por meio das atividades de produção, distribuição, circulação e consumo. Por isso, o estudo das bases físicas, como o relevo, hidrografia, tipos de solo e as variações climáticas é de fundamental importância para a ocupação humana de um território. Dessa maneira, tais fatores permitem que a relação sociedade e natureza sejam apreendidas, considerando processos históricos que, mesmo passíveis de generalização, têm suas particularidades definidas espacial e temporalmente (MAMIGONIAN, 2005).

Na esteira do grande varejo da diversidade dos setores no interior dos agronegócios ${ }^{6}$, procurou-se enfatizar a eficiência das atividades dentro das fazendas, com destaque para as lavouras (temporárias e permanentes) e a pecuária. Para tanto, foram selecionados os principais produtos com representatividade na produção, área plantada, valor bruto da produção e market share da pauta exportadora de Santa Catarina. Ainda do ponto de vista metodológico, utilizou-se a divisão mesorregional do estado de Santa Catarina, definida por IBGE (2012). Também, optou-se pela abordagem exploratória via levantamento bibliográfico e documental (GIL, 1994). Foram feitas análises de diferentes artigos, livros e teses, visando avaliar e situar a bibliografia relativa à

\footnotetext{
${ }^{6}$ Diferentemente de uma vasta bibliografia que associa agronegócio à produção de commodities e ao tamanho da área, define-se agronegócio como uma cadeia produtiva "que envolve desde a fabricação de insumos, passando pela produção nos estabelecimentos agropecuários, pela transformação e o seu consumo final" (CONTINI et al., 2006, p. 6). Esses segmentos dividem-se em: (1) pré-porteira (indústrias de bens de capital e indústrias químicas e de embalagens); (2) dentro da porteira (agropecuária, que corresponde às lavouras permanentes, lavouras temporárias, extrativismo vegetal e produção pecuária); e (3) pós-porteira (agrosserviços). Para uma tipologia da diversidade dos segmentos dos agronegócios, ver Gonçalves (2005).
} 
temática exposta. Didaticamente, o artigo foi desenvolvido com base em fontes primárias, secundárias e pesquisas de campo 7 .

O levantamento de dados estatísticos foi realizado nos relatórios da Produção Agrícola Municipal (PAM) e no Levantamento Sistemático da Produção Agrícola (LSPA), ofertados pelo Instituto Brasileiro de Geografia e Estatística (IBGE). Buscaram-se ainda informações na Síntese Anual da Agricultura Catarinense, publicada pela Empresa de Pesquisa Agropecuária e Extensão Rural de Santa Catarina (EPAGRI/CEPA), nos relatórios do Ministério da Agricultura, Pecuária e Abastecimento (MAPA), nos relatórios técnicos do Ministério do Desenvolvimento e do Ministério da Indústria e do Comércio Exterior (MDIC). Dentre as fontes secundárias, destacam-se artigos em periódicos indexados, teses, dissertações, livros e sítios de entidades empresariais e governamentais na internet.

Além desta introdução e das considerações finais, o texto divide-se em três itens: (1) destaca a ocupação territorial e as transformações nas estruturas agropecuárias catarinenses; (ii) apresenta a eficiência da produção e das exportações dos principais produtos agrícolas catarinenses e, por fim; (iii) traz considerações sobre o novo espraiamento territorial da agropecuária catarinense.

\footnotetext{
7 Segundo Cunha (2020, p. 42), "é sabido que para as pesquisas geoeconômicas, tanto regionais quanto gerais, dispõe-se de inúmeras bases de estatísticas e informações de instituições públicas e privadas. Sabe-se, também, que essas informações são alvo de duras lutas entre diversas classes de tecnocratas e burocratas, cujos objetivos são os questionamentos de métodos e técnicas de aferimento dessas estatísticas. Dessa forma, para fugir desse problema político, há uma solução: espírito crítico e a indiscrição, sob a forma de trabalho de campo, isto é, inquéritos e observações pessoais. Ou seja, a pesquisa baseada no trabalho de campo é, portanto, um elemento indispensável da percepção objetiva dos dados de base do raciocínio científico; quando ela está ausente, elaboram-se teorias que só têm relações longínquas com a realidade perceptível e que, por esse motivo, não têm qualquer utilidade social, pois não podem orientar a ação". Assim, as pesquisas de campo foram realizadas pelos autores, entre junho de 2016 e dezembro de 2019, com diversas instituições e produtores, nas seguintes mesorregiões do estado de Santa Catarina, polarizadas pelas seguintes cidades: Florianópolis, Chapecó, Lages, Canoinhas, Criciúma e Blumenau.
} 


\section{DA OCUPAÇÃO TERRITORIAL ÀS TRANSFORMAÇÕES NAS ESTRUTURAS AGROPECUÁRIAS CATARINENSES}

Do ponto de vista natural, o território catarinense "caracteriza-se por apresentar um altiplano levemente inclinado para o oeste e uma área que se desenvolve da borda do planalto até o mar [...]" (PELUSO Jr., 1991, p. 15), em termos humanos, sua ocupação ocorreu em quatro grandes fases, conforme demonstra a Figura 1.

A primeira fase foi caracterizada por duas correntes de povoamento. A partir de meados do século XVII, teve início a expansão dos vicentistas paulistas, em direção ao Sul, na base de concessão de sesmarias e de um povoamento esparso de baixa densidade demográfica. A segunda corrente de povoamento, oriunda do planalto paulista, deslocava-se em direção aos campos meridionais (WAIBEL, 1988). Nesses campos, como por exemplo, nos da região de Lages/SC, foram instaladas, desde o século XVIII, grandes estâncias de gado, que passaram a incorporar os índios sobreviventes como peões, "numa associação de relações feudais de propriedade e de trabalho", conforme demonstrou Mamigonian (1999, p. 68). Contudo, nas áreas de mata e vegetação campestre, foi desenvolvendo-se uma agricultura, explorada por arrendatários e agregados que dedicavam parte do seu tempo no plantio do trigo, milho, entre outros produtos, como bem demonstrou Peluso Jr (1991), em sua análise da fazenda do Cedro. 
Figura 1 - Ocupação do território catarinense

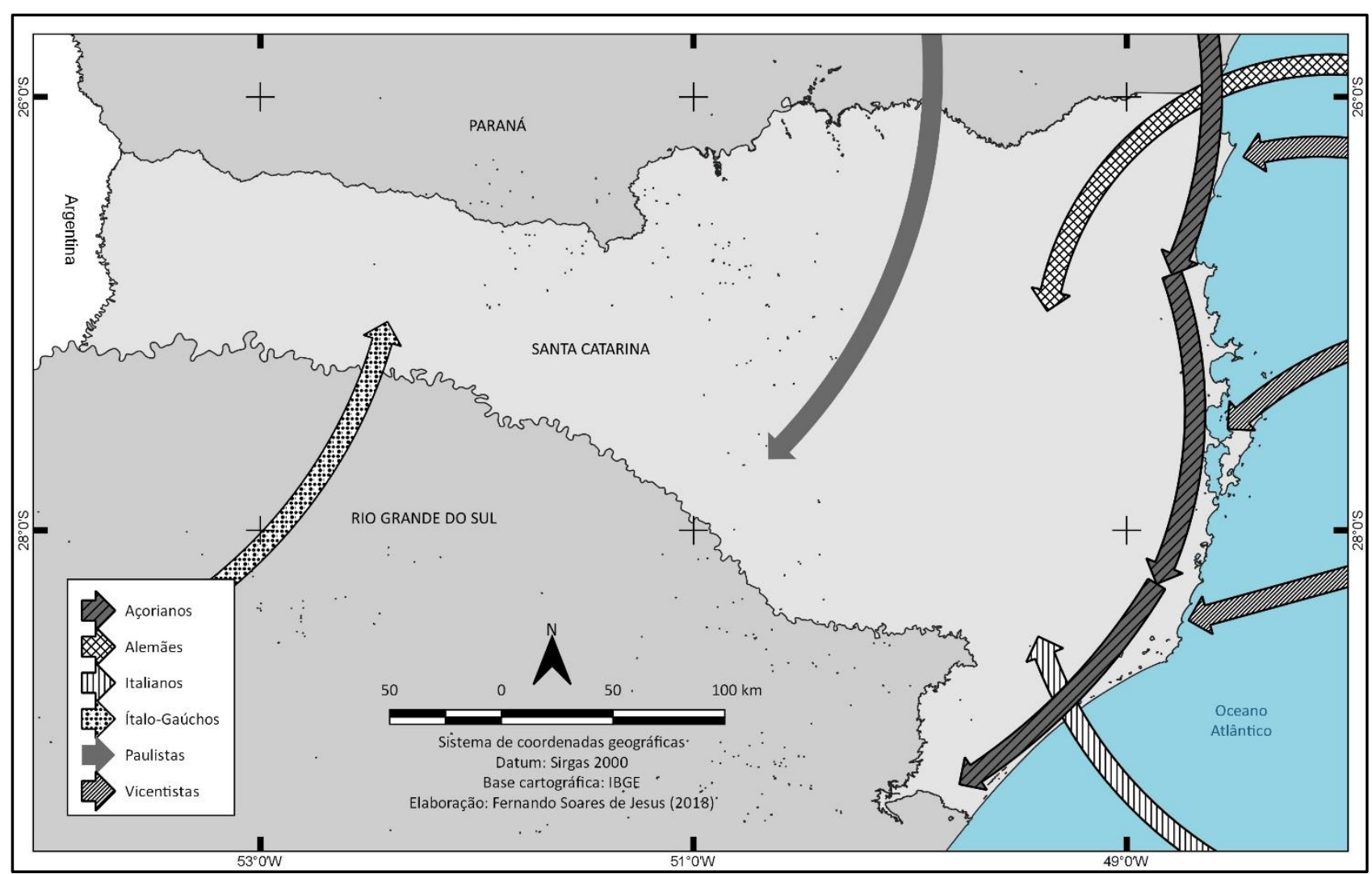

Fonte: IBGE (2012). Organização: autores.

Nas áreas litorâneas de núcleos esparsos, o governo português tratou de implantar, no século XVIII, o sistema de colonização com casais açorianos e madeirenses (WAIBEL, 1988). Essa colonização no litoral de Santa Catarina constituiu a maior intervenção geopolítica e geoeconômica do governo português no Sul do Brasil, e criou uma grande produção policultura, com exportações de farinha de mandioca (MAMIGONIAN, 1999). Tratou-se, portanto, da constituição da segunda grande fase de ocupação.

A partir dos anos de 1820, estabeleceram-se as primeiras colônias de povoamento, nas margens do Rio Negro/SC e em São Pedro de Alcântara/SC. Entretanto, foi somente a partir dos anos de 1840 que se estabeleceram definitivamente as colônias de povoamento. Uma denominada de colônia de Dona Francisca e a outra, no médio vale do rio Itajaí-Açu, conhecida como colônia Blumenau. A essa terceira fase constituída soma-se a implantação, no terceiro 
quartel do século XIX, das colônias italianas na parte Sul do território do estado de Santa Catarina (SOUTO MAIOR, 1968).

Por fim, o processo de ocupação completar-se-ia no início do século XX com a ocupação das terras do Oeste catarinense. Várias empresas de colonização e capitais comerciais intensificaram o comércio de terras no Oeste de Santa Catarina, retalhando-o em pequenos lotes. Esses lotes, por sua vez, seriam vendidos a descendentes de italianos e alemães provenientes do Rio Grande do Sul (ESPÍNDOLA, 2016a).

Nos vales atlânticos e nos do interior, estabeleceram-se milhares de pequenos agricultores, artesãos, operários, comerciantes, que já praticavam uma significativa divisão social do trabalho (MAMIGONIAN, 1966). No interior dessas propriedades, os produtores plantavam milho, trigo, alfafa, feijão, mandioca, batata; criavam porcos, galinhas, gado; e desenvolviam a colheita da erva-mate e a extração da madeira. Paralelamente, confeccionavam suas casas, seus galpões, suas ferramentas de trabalho e demais utensílios necessários para o desenvolvimento de seus trabalhos.

Diferentemente da região latifundiária, em que os agregados tinham a lavoura para o consumo próprio, nas áreas de colonização europeia, desenvolveuse uma pequena produção mercantil. À medida que essa estrutura produtiva se inseria na divisão social do trabalho, o complexo rural especializava-se e expelia para fora as atividades não agrícolas. Espírito Santo (1998) demonstrou que, desde o início do século XX, se intensificaram o uso de terras e a utilização de máquinas e de implementos agrícolas para a produção agropecuária.

Não obstante, foi a partir de 1950 e, principalmente, após 1960, com apoio estatal, que o processo de modernização da agricultura catarinense consolidou-se. As características marcantes na estrutura agropecuária catarinense, como a predominância da pequena agricultura, as questões topográficas, que inviabilizam o uso de máquinas, a menor disputa pela posse da terra, a diversidade produtiva nas propriedades agrícolas, entre outras, não impediram que a modernização pós- 
1960 ocorresse e tivesse seus efeitos também em Santa Catarina, conforme Marcondes (2016, p. 15) ${ }^{8}$.

No processo de modernização da agricultura, nas áreas de pequena produção mercantil, emergiram diferentes cadeias produtivas, como as de beneficiamento de carnes (bovina, avícola e suína), de leite e seus derivados, de fumo, de soja, de milho, de frutas, entre outras (SOUZA, 2014). Nas áreas de planalto, caracterizada pela pecuária extensiva, foram instalando-se madeireiros italianos e alemães do Rio Grande do Sul, como os Batistella, os Lüersen e Dall'Asta. Ainda em Campos Novos, Correia Pinto, Otacílio Costa, entre outras cidades, emergiram pequenas unidades produtoras de papel, papelão e pasta mecânica, como a Primo Tedesco, Trombini Papel e Embalagens, Iguaçu Papel e Celulose, Celulose Irani e outras

Essa moderna agropecuária está inserida em um ambiente em constante evolução e, nos anos de 1990, diante da abertura comercial, do fim do crédito rural, a sobrevalorização cambial e a redução de tarifas de importação de produtos agrícolas viram-se obrigadas a promover um intenso processo de reestruturação técnico-econômica9 9 .

\footnotetext{
${ }^{8}$ O processo de modernização da agricultura catarinense estava inserido no conjunto das transformações implementadas para o setor agropecuário pelo governo brasileiro. Tratou-se, com o apoio estatal, de aprofundar a dinâmica capitalista por meio da intensa integração da agricultura e indústria (NEUMANN; FAJARDO; MARIN; 2017).

${ }^{9}$ Dentre as principais reestruturações, destacam-se o aumento das fusões e aquisições, a desnacionalização de diferentes segmentos, as terceirizações, a incorporação de novas tecnologias, a redução do ciclo completo na suinocultura, o abandono e redirecionamento para novas atividades (turismo rural, agroindústrias familiares, pequenas cooperativas, etc.), uma maior integração vertical e horizontal nas cadeias produtivas, a redução do número de produtores menos capitalizados e com menor produtividade, em contraposição à ampliação da importância dos produtores com melhor nível técnico, a ampliação da capacidade produtiva, especialização produtiva, o surgimento de novos mecanismos de financiamento e de crédito aos agronegócios (o Certificado de Mercadoria com Emissão de Garantia, a Cédula do Produto Rural, o Certificado de Depósito Agropecuário, o Warrant Agropecuário, o Certificado de Direitos Creditórios do Agronegócio, a Letra de Comércio Agrícola e o Certificado de Recebíveis do Agronegócio e o Programa Nacional de Fortalecimento da Agricultura Familiar), entre outras (ESPÍNDOLA; CUNHA, 2020).
} 
A combinação do processo de reestruturação técnico-econômica e os novos mecanismos de financiamento possibilitaram que, no período entre 1985 e 1999, a agricultura catarinense crescesse a uma taxa superior da agricultura do Sul do Brasil e da brasileira. Assim, enquanto a agricultura catarinense cresceu $83 \%$, a do Sul do país aumentou $67 \%$, e a brasileira 54\%. Isso possibilitou uma crescente participação da agropecuária catarinense no conjunto da agropecuária brasileira, pois, se, em 1985, a agropecuária catarinense representava 5,2\% da brasileira, em 1999, esse percentual alcançou 6,4\%.

Como já dito, a partir de 2003, a economia brasileira apresentou dois ciclos de crescimento econômico distintos. Em Santa Catarina, no período de 2003-2011, o PIB cresceu de 62 milhões para 169 milhões, o que representou um aumento de 2,7 vezes, reduzindo-se para 2,6\%, em 2016. Nessa conjuntura, pergunta-se: qual foi a eficiência produtiva e exportadora dos principais produtos da agropecuária catarinense? ${ }^{10}$

\footnotetext{
10 Não é de maneira alguma desnecessário recordar que, à luz dos acontecimentos nos últimos cinquenta anos, a agricultura brasileira transformou-se em um ramo especializado, competitivo e dinâmico e conseguiu se consolidar no mercado mundial de alimentos e de produtos agrícolas. Saiu de uma agricultura de baixa produtividade e de inovações tecnológicas escassas para uma produção agrícola de alta produtividade e com savoir-faire tecnológico, uma vez que conseguiu forjar suas vantagens competitivas dinâmicas agroindustriais, e essas são atreladas às combinações geográficas (CUNHA, 2020). Entretanto, mesmo não sendo o objetivo central deste texto, não é quase implausível assinalar que as transformações modernas na agricultura não se deram de modo harmônico no território nacional. Assim, a maioria tanto dos estabelecimentos rurais quanto dos trabalhadores agrícolas não se modernizou e vive ainda em condições precárias e em consonância com a agricultura de subsistência. Não houve mudanças significativas na estrutura fundiária, o nível de concentração de terra praticamente ficou inalterado. O valor de produção é bastante desigual, o nível educacional dos produtores, no geral, é baixo, a orientação técnica é diminuta na maioria dos estabelecimentos. Também, há mortes por conflitos de terras, sobretudo em áreas de fronteiras e terras demarcadas. A população do campo, em grande parte, ainda sofre de desnutrição e sobrevive com auxílios de programas de transferência de renda - bolsa família e aposentadoria rural, em especial, no Norte e Nordeste (CUNHA, 2020). Para lúcida análise sobre essas disparidades no campo brasileiro, ver: Klein e Luna (2020).
} 


\section{DESEMPENHO DA PRODUÇÃO E DA EXPORTAÇÃO DOS PRINCIPAIS PRODUTOS AGRÍCOLAS CATARINENSES}

Apesar da redução da participação da agropecuária catarinense no PIB em 3\% entre 2002 e 2011, constata-se a sua importância significativa na geração de renda na economia do estado. Entre 2003-2020, o VBP cresceu de R\$11,7 bilhões para $\mathrm{R} \$ 28,3$ bilhões, o que revela um crescimento da ordem de 2,4 vezes (BRASIL, 2021a). Esse valor gerado representou 3,3\% de todo o valor gerado pela agropecuária brasileira. Em 2020, o VBP das lavouras catarinenses participava com 1,8\% do total gerado nas lavouras brasileiras (10,3 bilhões de reais). Na pecuária, o VBP passou, entre 2005 e 2020, de R $\$ 10$ bilhões para R\$17,9 bilhões, $-6,5 \%$ do total de valor da pecuária brasileira (BRASIL, 2021a).

Desagregando-se o VBP, nota-se que, enquanto o total do valor gerado pelas lavouras temporárias cresceu de $\mathrm{R} \$ 3,7$ bilhões para $\mathrm{R} \$ 9,1$ bilhões, o valor nas lavouras permanentes passou de $\mathrm{R} \$ 510$ milhões para R $\$ 1,3$ bilhão (BRASIL, 2021a). Em termos de produto, o VBP da produção de soja em Santa Catarina cresceu de $\mathrm{R} \$ 403$ milhões de reais, em 2003, para 4,2 bilhões, em 2020, representando cerca de $2 \%$ do VBP do total dessa cultura no Brasil. Destaca-se ainda o crescimento do valor verificado na produção de milho e fumo que cresceram, respectivamente, de $R \$ 1,1$ bilhão para $R \$ 2,3$ bilhões e de $R \$ 812$ milhões para $R \$ 2,2$ bilhões (BRASIL, 2021a). Outras culturas, como, por exemplo, arroz, maçã, trigo, banana, também tiveram crescimento nos valores auferidos no período de 2003-2020. Na pecuária, enquanto o VBP, entre 2008-2020, da produção de bovinos cresceu 162,7\%, passando de $R \$ 685$ milhões de reais para $R \$ 1,8$ bilhão, o valor da produção de suínos cresceu 350\%, passando de $R \$ 1,4$ bilhão para $R \$ 6,3$ bilhões, e o do leite cresceu $200 \%$, saindo de $R \$ 1,6$ bilhão para $R \$ 4,8$ bilhões. Somente o valor bruto da produção de frango passou, no mesmo período, de 5,9 bilhões para 10,4 bilhões, 
representando $14,1 \%$ do total gerado na produção de frango no Brasil (BRASIL, 2021a).

O desempenho favorável do VBP contrastou com o declínio da área plantada da lavoura permanente em 3,5\%, passando de 78.392 hectares para 75.638 hectares, e da área das culturas temporárias em 17,64\%, reduzindo-se de 1,7 milhão de ha para 1,4 milhão, entre 2003-2019 (IBGE, 2021a). Assim, conforme se observa na Tabela 1, entre 2003-2019, a área plantada com feijão caiu de 146 mil ha para 63 mil hectares, e a de milho reduziu-se de 856 mil hectares para 344 mil hectares.

Tabela 1- Santa Catarina - Quantidade produzida e área plantada (2003-2019)

\begin{tabular}{lcccc}
\hline \multicolumn{2}{c}{ Quantidade produzida em toneladas } & \multicolumn{2}{c}{ Área plantada em hectares } \\
\hline Produto/ano & $\mathbf{2 0 0 3}$ & $\mathbf{2 0 1 9}$ & $\mathbf{2 0 0 3}$ & $\mathbf{2 0 1 9}$ \\
Alho & 15.656 & 15.434 & 2.145 & 1.655 \\
Arroz & 1.034 .558 & 1.062 .159 & 143.670 & 143.072 \\
Batata-inglesa & 128.207 & 117.483 & 10.083 & 4.607 \\
C. de açúcar & 648.989 & 185.602 & 16.728 & 3.849 \\
Cebola & 409.553 & 457.221 & 25.905 & 17.237 \\
Feijão & 188.626 & 108.976 & 146.942 & 63.684 \\
Fumo em folha & 213.339 & 192.269 & 120.899 & 90.174 \\
Mandioca & 538.930 & 348.412 & 28.417 & 16.927 \\
Milho & 4.310 .934 & 2.767 .069 & 856.427 & 344.237 \\
Soja & 712.175 & 2.270 .512 & 257.086 & 665.548 \\
Tomate & 129.096 & 161.948 & 2.507 & 2.468 \\
Trigo & 171.969 & 146.039 & 77.541 & 48.737 \\
Maçã & 475.095 & 585.790 & 16.348 & 15.198 \\
Banana & 618.403 & 723.435 & 29.714 & 29.364 \\
\hline
\end{tabular}

Fonte: IBGE (2021a). Organização dos dados: autores

A redução da área plantada de milho em 59,8\%, combinada com a queda da produção em 35,8\% e com o aumento de consumo pela avicultura, suinocultura e bovinocultura de leite, ampliou o deficit estadual de milho. "Parte dessas áreas de milho e feijão, particularmente a de milho, passou a ser utilizada para o plantio de soja; outra parte passou a ser usada para o plantio de milho para silagem; 
enquanto o restante simplesmente deixou de ser utilizado para a produção de grãos" (MARCONDES, 2016, p. 19) ${ }^{11}$.

Em contrapartida, enquanto a área plantada de soja foi ampliada de 257 mil ha para 665 mil hectares, a área plantada de pinus, juntamente com a de eucaliptos, cresceu, respectivamente, de 148 mil hectares para 610 mil hectares, e de 20 mil para 324 mil hectares (IBGE, 2021c). No caso das matas plantadas, "nos anos de 1980, intensificou-se o plantio de pinus em áreas de pastagens naturais/naturalizadas e, recentemente, expandiu-se o plantio de eucalipto" (MARCONDES, 2016, p. 19) ${ }^{12}$.

A queda da área plantada manifestou-se ainda nas culturas de trigo, cebola, alho ${ }^{13}$ e arroz. A redução da área de pastagens e de lavouras temporárias não provocou arrefecimento da produção total. Excetuando-se a produção de fumo, milho, feijão e madeira para outras finalidades, os demais produtos das culturas temporárias e permanentes (maçã e banana) apresentaram evolução no total produzido.

A queda da produção de feijão, em 42\% (Tabela 1), entre 2003-2019, pode ser explicada por três fatores. Enquanto o primeiro fator decorre das adversidades

\footnotetext{
11 Informações confirmadas em entrevistas realizadas, com agricultores e suas famílias, entre junho de 2016 e dezembro de 2019, na mesorregião Oeste Catarinense.

${ }^{12}$ Cabe ressaltar que, enquanto a produção de madeira para outras finalidades reduziu-se $24,2 \%$, a produção de madeira para papel e celulose cresceu apenas 1,3\%, com declínio crescente iniciado em 2009. Em 2008, Santa Catarina possuía $11 \%$ da área de florestas plantadas com pinus e eucalipto no país, caracterizando-se como o quarto estado maior exportador de produtos florestais, em valor (37\% dos móveis de madeira, $31 \%$ da madeira e suas obras e $11 \%$ do papel). A queda da produção catarinense está diretamente vinculada a três fatores: (1) a forte redução no ritmo da construção civil nos EUA em razão da crise hipotecária (GONÇALVES, 2008); (2) câmbio valorizado; e (3) queda dos preços das toras (EPAGRI/CEPA, 2009). Informações confirmadas em entrevistas realizadas, com agricultores e suas famílias, entre junho de 2016 e dezembro de 2019, na mesorregião Serrana Catarinense.

${ }^{13}$ A produção de alho em Santa Catarina, entre 2003-2019, ficou praticamente estável mesmo com uma redução de área em 21,4\% (IBGE, 2021a). Os preços baixos recebidos pelos produtores, as dificuldades de comercialização e das elevadas importações constituem-se os principais fatores para esse movimento estabilizado de sua produção. Entre 2003-2011, as importações de alho subiram de 91.565 toneladas para 162.236 toneladas, em 2011 (BRASIL, 2021b). Informações confirmadas em entrevistas realizadas, com agricultores e suas famílias, entre junho de 2016 e dezembro de 2019, na mesorregião Serrana Catarinense.
} 
climáticas, que resulta em perda de qualidade e de produtividade dos grãos, o segundo refere-se à estabilidade do consumo desse tipo de alimento e o terceiro em virtude do aumento da produção dos demais estados produtores. O Paraná, por exemplo, aumentou a sua produção de 707 mil toneladas, em 2003, para 815 mil toneladas, em 2011. Esse aumento também foi verificado nos estados de Minas Gerais e de Goiás (EPAGRI/CEPA, 2004; 2017; IBGE, 2021a) ${ }^{14}$.

Na fumicultura, apesar dos movimentos ascendentes dos preços desde 2006, ocorrem momentos de expansão e decréscimo da produção, em virtude das adversidades climáticas (geada, granizo e excesso de chuvas), ocorridas em 2009/2010 e da mão de obra, cada vez mais cara e escassa (EPAGRI/CEPA, 2004; 2017; IBGE, 2021a) ${ }^{15}$. Entre 2003-2019, a quantidade produzida reduziu-se de 213 mil toneladas para 192,2 mil toneladas, perfazendo uma queda de 9,7\%.

Segundo os dados da Tabela 1, ao longo do período analisado, a produção de arroz apresenta-se estável, com uma produção em torno de 1,0 milhão de toneladas, em decorrência de alguns fatores, como a retirada de áreas de arroz para a produção de sementes, o custo médio de produção (no sistema prégerminado) maior que os preços obtidos pelos produtores, arrendamento de terras de cultivo de arroz para outras culturas, problemas climáticos desencadeados pelo fenômeno El Niño. Tais fatores contribuíram ao mesmo tempo para que a produtividade média se estabilizasse, desde 2002, em torno de $7.200 \mathrm{~kg} / \mathrm{ha}$ (IBGE, 2021a) ${ }^{16}$.

Com cerca de oito mil famílias dedicadas à produção, Santa Catarina é o maior produtor nacional de cebola. Em 2019, a produção foi de 457,2 mil toneladas, o que representou um crescimento de $12 \%$ em relação ao ano de 2003 . O pouco

\footnotetext{
${ }^{14}$ Informações confirmadas em entrevistas realizadas, com agricultores e suas famílias, entre junho de 2016 e dezembro de 2019, na mesorregião Oeste Catarinense.

15 Informações confirmadas em entrevistas realizadas, com agricultores e suas famílias, entre junho de 2016 e dezembro de 2019, na mesorregião Norte Catarinense.

${ }^{16}$ Informações confirmadas em entrevistas realizadas, com agricultores e suas famílias, entre junho de 2016 e dezembro de 2019, na mesorregião Sul Catarinense.
} 
dinamismo relativamente ao ano de 2003 ocorreu por conta do excesso de chuvas durante todo o período de desenvolvimento e colheita da cultura (IBGE, 2021a) ${ }^{17}$.

O crescimento da produção de soja de 712 mil toneladas, em 2003, para 2,2 milhões de toneladas, em 2019, poderia estar diretamente associado à expansão da área plantada. Contudo, conforme Cunha e Cruz (2017, p. 753), para além da conjuntura econômica e da estrutura técnica produtiva, um fator que ajuda a elucidar esse crescimento é a relação preço/custo da soja no mercado e a renda possibilitada por essa cultura, que influencia diretamente na escolha entre a soja, e como, por exemplo, o milho, uma vez que a relação entre custos de produção e da capacidade de rendimento das culturas, em geral, quando o preço da soja é pelo menos 2,3 vezes o preço do milho, a produção de soja é mais favorável ao produtor, que opta pela oleaginosa.

Além disso, afora as boas condições climáticas, os preços favoráveis e as medidas político-institucionais ${ }^{18}$, o crescimento da produção das lavouras catarinenses explica-se igualmente pelo aumento da produtividade e a crescente inserção no mercado internacional. Entre 2003-2019, enquanto o rendimento médio do milho cresceu de 5.033 quilogramas por hectares para $8.041 \mathrm{Kg} / \mathrm{ha}$, a produtividade do arroz estabilizou-se, e a da soja aumentou $26 \%$ contra $36,7 \%$ da do rendimento da cultura de feijão (IBGE, 2021a).

Na pecuária, apesar da redução das áreas de pastagens e diminuição do número de produtores de suínos e de aves ${ }^{19}$, a produção aumentou. Entre 2013-

\footnotetext{
17 Informações confirmadas em entrevistas realizadas, com agricultores e suas famílias, entre junho de 2016 e dezembro de 2019, na mesorregião Norte Catarinense.

${ }^{18}$ Dentre as políticas públicas do Governo Federal destacam-se: (a) Política Nacional de Segurança Alimentar e Nutricional (PNSAN); (b) Programa Nacional de Alimentação Escolar (PNAE); (c) Programa de Aquisição de Alimentos (PAA); (d) Programa de Garantia de Preços para a Agricultura Familiar (PGPAF); entre outros. Para o conjunto da agropecuária, o governo brasileiro direcionou o BNDES e o Banco do Brasil como principais agentes do financiamento agropecuário (PADILHA; ESPÍNDOLA, 2015). ${ }^{19}$ Segundo Marcondes (2016), na suinocultura, o processo de concentração/exclusão ganhou força já nos anos de 1990 e se deu de maneira bem mais contundente do que na avicultura. Segundo Espíndola (2016b), existem atualmente apenas 7.500 suinocultores, sendo apenas $15 \%$ deles independentes. Entre 2014 e 2019, o número de produtores caiu 12,13\% e o estado possui, também, cerca de 60 mil produtores de suínos de subsistência (EPAGRI/CEPA, 2020). Informações confirmadas
} 
2019, o número de matrizes de suínos alojadas no estado de Santa Catarina cresceu de 690,7 mil cabeças para 817,9 mil cabeças, o que representa $17 \%$ das matrizes alojadas no Brasil (IBGE, 2021b). Em termos de produção, o número de animais suínos abatidos, conforme Tabela 2, passou de 7,3 milhões de cabeças, em 2003, para 12,3 milhões, em 2019. Entre 2003-2019, a variação do crescimento da produção de carne suína foi de $73,8 \%$ contra $68,4 \%$ do número de abatidos.

Tabela 2 - Produção da pecuária catarinense - 2003-2019

\begin{tabular}{|c|c|c|c|}
\hline \multicolumn{2}{|c|}{ Rebanho 2003} & \multicolumn{2}{|c|}{ Rebanho 2019} \\
\hline Suíno & 5,4 milhões de cabeças & Suíno & 7,5 milhões de cabeças \\
\hline Bovino & 3,1 milhões de cabeças & Bovino & 4,4 milhões de cabeças \\
\hline Frangos & $\begin{array}{c}\text { 145,6 milhões de } \\
\text { cabeças }\end{array}$ & Frangos & 130,6 milhões de cabeças \\
\hline \multicolumn{2}{|c|}{ Produção 2003} & \multicolumn{2}{|c|}{ Produção 2019} \\
\hline Leite & 1,3 bilhão de litros & Leite & 3,04 bilhões de litros \\
\hline $\begin{array}{c}\text { Vacas } \\
\text { ordenhadas }\end{array}$ & 643,4 mil cabeças & $\begin{array}{c}\text { Vacas } \\
\text { ordenhadas }\end{array}$ & 796,5 mil cabeças \\
\hline Abate bovino & 243,2 mil cabeças & Abate bovino & 536,1 mil cabeças \\
\hline $\begin{array}{l}\text { Qt. de carne } \\
\text { bovina }\end{array}$ & 50,9 mil toneladas & $\begin{array}{l}\text { Qt. de carne } \\
\text { bovina }\end{array}$ & 122,6 mil toneladas \\
\hline Abate suíno & 7,3 milhões de cabeças & Abate suíno & 12,3 milhões de cabeças \\
\hline $\begin{array}{l}\text { Qt. de carne } \\
\text { suína }\end{array}$ & 643,6 mil toneladas & $\begin{array}{l}\text { Qt. de carne } \\
\text { suína }\end{array}$ & $1.119,1 \mathrm{mil}$ toneladas \\
\hline Abate frango & $\begin{array}{l}662,4 \text { milhões de } \\
\text { cabeças }\end{array}$ & Abate frango & 818,2 milhões de cabeças \\
\hline $\begin{array}{l}\text { Qt. de carne } \\
\text { frango }\end{array}$ & $1.332,9$ mil toneladas & $\begin{array}{l}\text { Qt. de carne } \\
\text { frango }\end{array}$ & $1.936,2$ mil toneladas \\
\hline
\end{tabular}

Fonte: IBGE (2021b; 2021d). Organização dos dados: autores

Apesar desse dinamismo, cabe salientar que a pecuária de carne suína e aves vem perdendo participação relativa no conjunto da região Sul e no Brasil. Entre

em entrevistas realizadas, com agricultores e suas famílias, entre junho de 2016 e dezembro de 2019, na mesorregião Oeste Catarinense. 
2003-2019, enquanto o abate de suínos em Santa Catarina teve um aumento de 68,5\%, o abate do Rio Grande do Sul cresceu 109,9\%, contra 185,3\% do Paraná e 1.896,2\% de Goiás (IBGE, 2021d). No abate de aves, o crescimento de Santa Catarina, no mesmo período, foi de $23,5 \%$ contra $842 \%$ de Goiás e $233,6 \%$ do Paraná (IBGE, 2021d). Em 2003, enquanto o estado do Mato Grosso participava com 1,7\% do abate nacional, o estado de Goiás representava 2,6\%. Em 2019, Goiás subiu sua participação para 6,1\%, enquanto o Mato Grosso ampliou sua participação para 4,9\% (IBGE, 2021d).

Ainda na Tabela 2, observa-se que a quantidade produzida de carne suína, em Santa Catarina, aumentou, entre os anos analisados, $73,8 \%$ e a de carne de frango, 48,4\%. Assim, também houve destaque no volume produzido de leite, uma vez que, no período, aumentou 133\%; contudo, a ordenha de vacas evoluiu mais lentamente, na casa de $24 \%$. Cabe ainda destacar o volume de produção da carne bovina, cujo aumento, entre 2003 e 2019, foi de 140\%.

Portanto, verifica-se uma nova divisão territorial do trabalho, com o aumento de participação do estado do Paraná e do Centro-Oeste, que, conforme a bibliografia consultada, decorre do deficit estadual de milho, o que tem forçado as agroindústrias de aves e suínos para essas novas áreas (MARCONDES, 2016). Entretanto, Espíndola (2009) salienta que as inversões se fizeram ainda para o Nordeste e Norte do país e, que, assim, fatores como economia de escala e de envergadura (mega-abatedouros, novos sistemas criatórios, menor e outro tipo de produtor), economia de custo de transação na aquisição de insumos, proximidade dos mercados consumidores em potencial de crescimento, estratégias de fusões e aquisições contribuem para a explicação dessa nova configuração territorial.

Além do crescimento da produção e dos índices de produtividade, os produtos agrícolas apresentaram dinamismo em suas exportações. Os agronegócios são responsáveis por $69,5 \%$ das exportações totais do estado de Santa Catarina e 6,4\% das vendas externas totais dos bens da agropecuária 
brasileira. Conforme Gráfico 1, entre 2003-2019, as receitas auferidas no mercado externo apresentaram um crescimento de 2,52 vezes, passando de US\$ 2,4 bilhões, para US\$ 6,2 bilhões. Em contrapartida, as exportações totais catarinenses cresceram 2,4 vezes, passando de US\$ 3,7 bilhões para US $\$ 8,9$ bilhões.

Gráfico 1 - Exportações dos produtos agrícolas catarinenses (2003-2019)

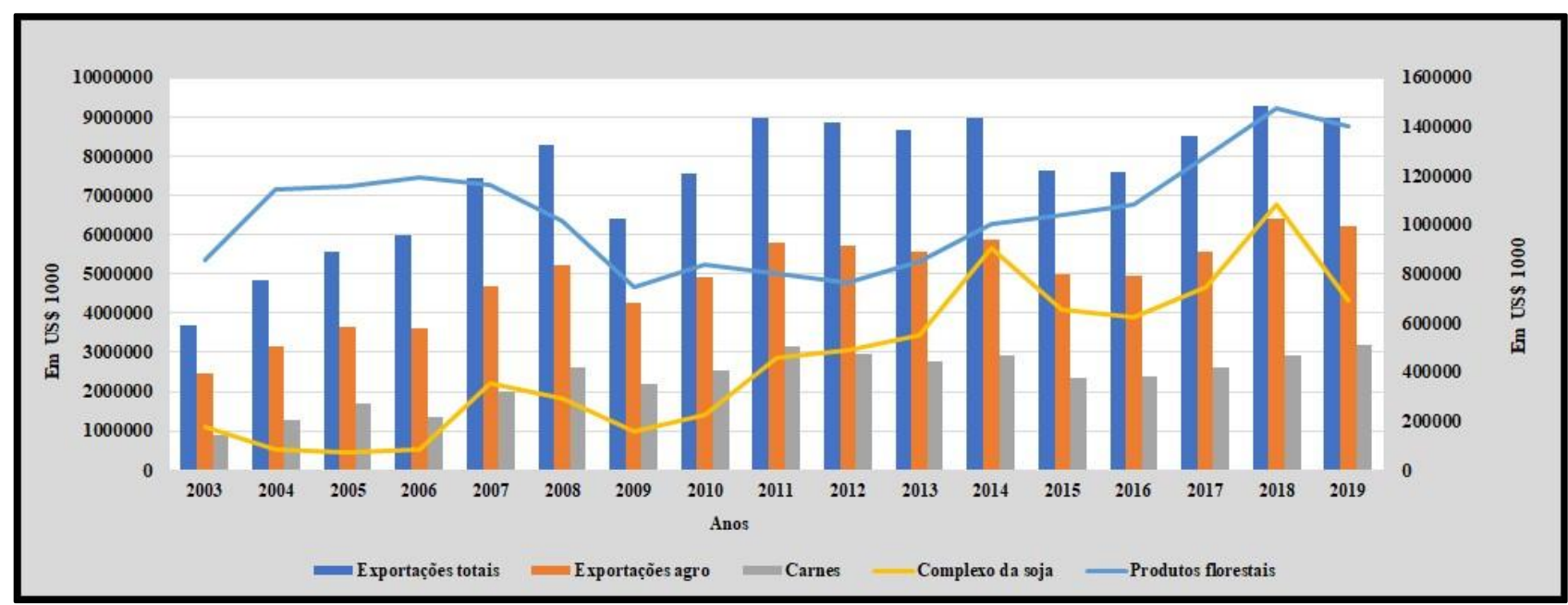

Fonte: Brasil (2021b). Organização dos dados: autores

Em termos de produtos, enquanto as exportações do complexo da carne cresceram 265\%, passando, entre 2003-2019, de US\$ 877 milhões para US\$ 3,2 bilhões, as exportações de produtos do complexo soja alcançaram uma porcentagem de $288 \%$, contra um aumento percentual de $64,7 \%$ dos produtos florestais, no mesmo período. As exportações da agropecuária, total em 2019, concentram-se, principalmente, em produtos como carne de frango $(35,4 \%)$, madeira $(17,1 \%)$, suíno $(13,9 \%)$, grãos de soja $(10,4 \%)$, tabaco e derivados $(5,3 \%)$, e papel (4,3\%) (BRASIL, 2021b).

Verifica-se, nos dados do Gráfico 1, um momento de queda das exportações entre 2012-2013 e outro entre 2014-2016. Enquanto no primeiro momento, as exportações reduziram-se 3,6\%; no segundo, decaíram de $U \$ 5,7$ bilhões para US\$ 4,8 bilhões, o que representou uma queda de $16 \%$. Contribuíram para a diminuição das exportações a queda dos volumes exportados pelos produtos de origem animal, entre 2012-2013, e animal e vegetal, entre 2014-2016. A redução de 
15\% do valor total exportado em 2015, em relação a 2014, resultou da queda das exportações das principais mercadorias, como carne de frango, com diminuição de 18\%; a soja, com 28\%; e a carne suína, com $26 \%{ }^{20}$. Segundo Epagri/Cepa (2017, p. 15), "as receitas com exportações só não caíram de forma mais acentuada porque os volumes embarcados têm crescido de um modo geral e compensado parte das quedas dos preços médios obtidos"21.

Dessa maneira, os desempenhos da produção, da produtividade e das exportações ${ }^{22}$ dos bens agrícolas catarinenses manifestam-se territorialmente, pois a produção, apesar de diversificada, está desigualmente distribuída, promovendo, ao longo de sua evolução, concentrações produtivas territoriais.

\footnotetext{
${ }^{20}$ Apesar de Santa Catarina ser um grande exportador de carnes, suas exportações estão constantemente sujeitas a restrições de ordem tarifária e não tarifária. Destaca-se ainda que esses produtos vêm perdendo participação no mercado internacional para outros estados concorrentes. $\mathrm{Na}$ produção de carne suína, apesar de Santa Catarina conjuntamente com o Rio Grande do Sul concentrarem $60 \%$ de toda a carne exportada pelo Brasil, existe uma nova dinâmica de participação dos estados brasileiros na divisão internacional do trabalho, com destaque para Goiás e Minas Gerais (ESPÍNDOLA, 2016b; 2016c). Na carne de frango, o estado compensa a perda de volume com os ganhos em valores, pois suas exportações são de produtos mais elaborados (cortes, produtos temperados, desossados, dentre outros).

${ }^{21}$ Nos últimos anos, a queda das exportações agrícolas catarinenses acompanha a diminuição geral das exportações totais catarinenses. Entre 2012-2016, as exportações totais catarinenses reduziram-se de um montante de $U \$ 8,9$ bilhões para $U \$ 7,5$ bilhões, representando uma redução de $16 \%$. A participação catarinense nas exportações totais brasileiras vem diminuindo, enquanto a sua participação nas importações vem aumentando. As exportações brasileiras entre 2003-2015 cresceram $247 \%$ e a catarinense 182\%, no mesmo período (ESPÍNDOLA, 2016b).

22 O desempenho exportador da agropecuária catarinense acompanha, desde 2003, tendência de crescimento das exportações dos produtos agrários brasileiros. Não obstante, houve aumento de quase dez vezes das importações totais dos produtos agrícolas catarinenses, que subiram de 296 mil dólares para US\$2,3 bilhões (BRASIL, 2021b), entre 2003-2019; mesmo assim, pode-se concluir que as exportações catarinenses apresentaram, no referido período, desempenhos favoráveis, que contribuíram para os saldos positivos de sua balança comercial do estado.
} 


\section{CONSIDERAÇÕES SOBRE O NOVO ESPRAIAMENTO TERRITORIAL DA AGROPECUÁRIA CATARINENSE}

No estado de Santa Catarina, as mesorregiões, conforme Figura 2 , denominadas e classificadas por IBGE (2012), apresentaram, entre 2003-2019, comportamentos não semelhantes; entretanto, com a mesma propensão de crescimento dinâmico em termos de valor adicionado bruto da produção, porém com involução de área plantada, com exceção das mesorregiões Norte Catarinense e Serrana. Em 2019, 95,3\% da área plantada total do estado representava as lavouras temporárias, contra menos de $5 \%$ da área destinada às lavouras permanentes (IBGE, 2021a).

\footnotetext{
${ }^{23}$ Segundo Cunha e Farias (2019, p. 145), “o IBGE apresentou uma nova divisão regional no Brasil vinculada aos processos sociais, políticos e econômicos sucedidos em território nacional desde a última versão da Divisão Regional do Brasil, publicada na década de 1990. As unidades mesorregionais e as microrregionais recebem, respectivamente, os nomes de regiões geográficas intermediárias e regiões geográficas imediatas. O recorte dessas incorpora as mudanças ocorridas no Brasil ao longo das últimas três décadas. O processo socioespacial recente de fragmentação/articulação do território brasileiro, em seus mais variados formatos, pode ser visualizado em vários estudos desenvolvidos no IBGE. O recurso metodológico utilizado na elaboração da presente Divisão Regional do Brasil valeu-se dos diferentes modelos territoriais oriundos de estudos pretéritos, articulando-os e interpretando a diversidade resultante". Nesta seção, foram considerados os novos critérios; porém, foram adotados os nomes das seis mesorregiões: Oeste Catarinense; Norte Catarinense; Serrana; Vale do Itajaí; Grande Florianópolis; e Sul Catarinense.
} 
Figura 2 - Mesorregiões do estado de Santa Catarina

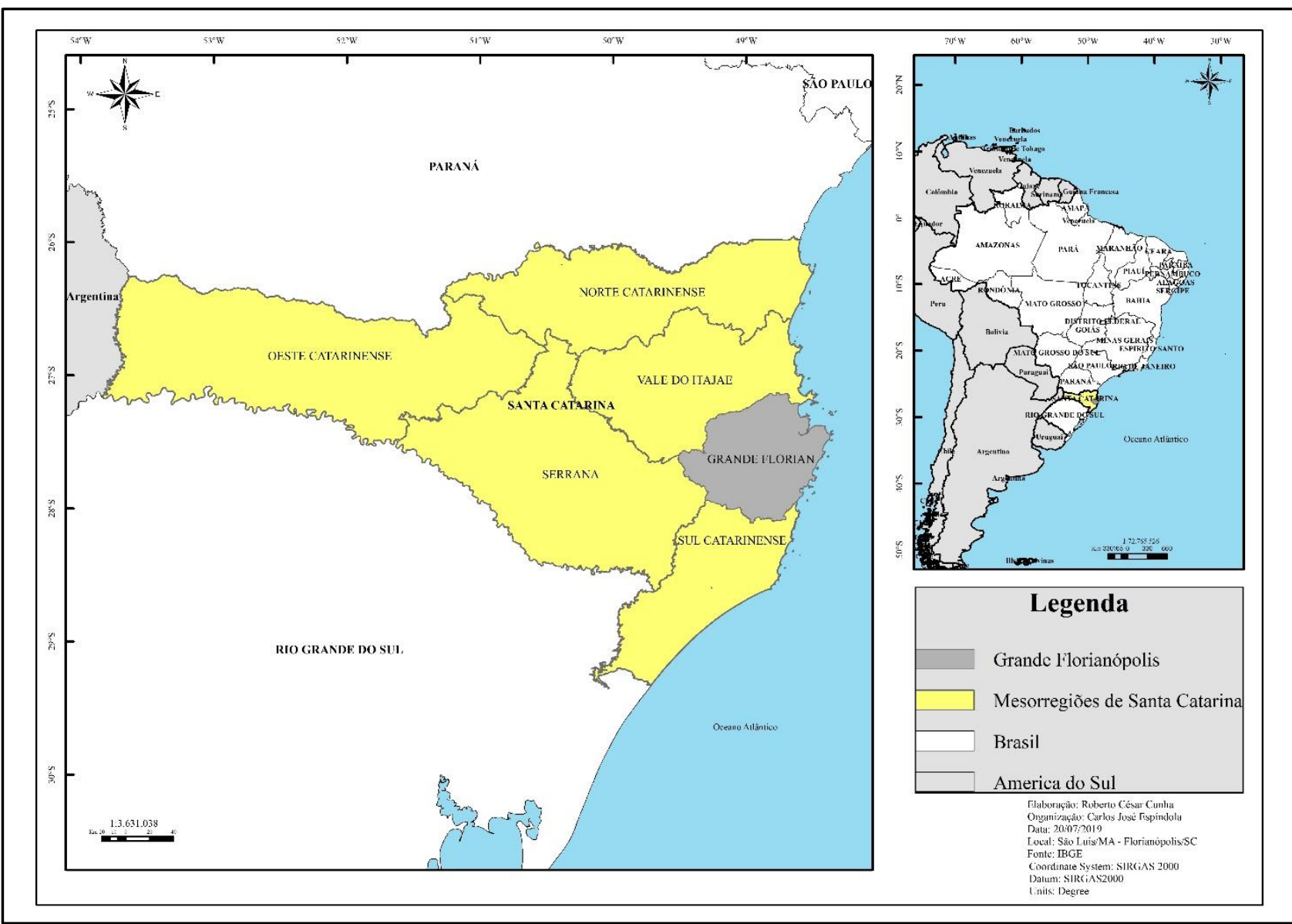

Fonte: IBGE (2012). Organização dos dados: autores

Assim sendo, entre as mesorregiões do estado catarinense, como assinala o Gráfico 2, as mesorregiões Norte e Serrana são as únicas que obtiveram dinamismo positivo, mantiveram-se em segundo e terceiro lugares, pela ordem, na utilização do solo para as lavouras temporárias. O acréscimo, entre 2003 e 2019, foi de $13,9 \%$ na mesorregião Norte e $17,8 \%$ na Serrana. Apesar disso, a mesorregião Oeste Catarinense, a maior em aproveitamento da terra, diminuiu, no período, 30,2\% (271,8 mil hectares). Nos mesmos anos em análise, seja na quarta maior mesorregião (Sul Catarinense), seja na quinta (Vale do Itajaí), as culturas temporárias também decresceram suas áreas plantadas, respectivamente, em 18,9\% (recuo de 33,8 mil hectares) e 21,2\% (perda de 31,6 mil hectares). Para mais, ainda 
no Gráfico 2, a mesorregião Grande Florianópolis não conseguiu elevar sua área plantada, totalizando um decréscimo de $44 \%{ }^{24}$.

Gráfico 2 - Área plantada de lavouras temporárias das mesorregiões de Santa Catarina (hectares)

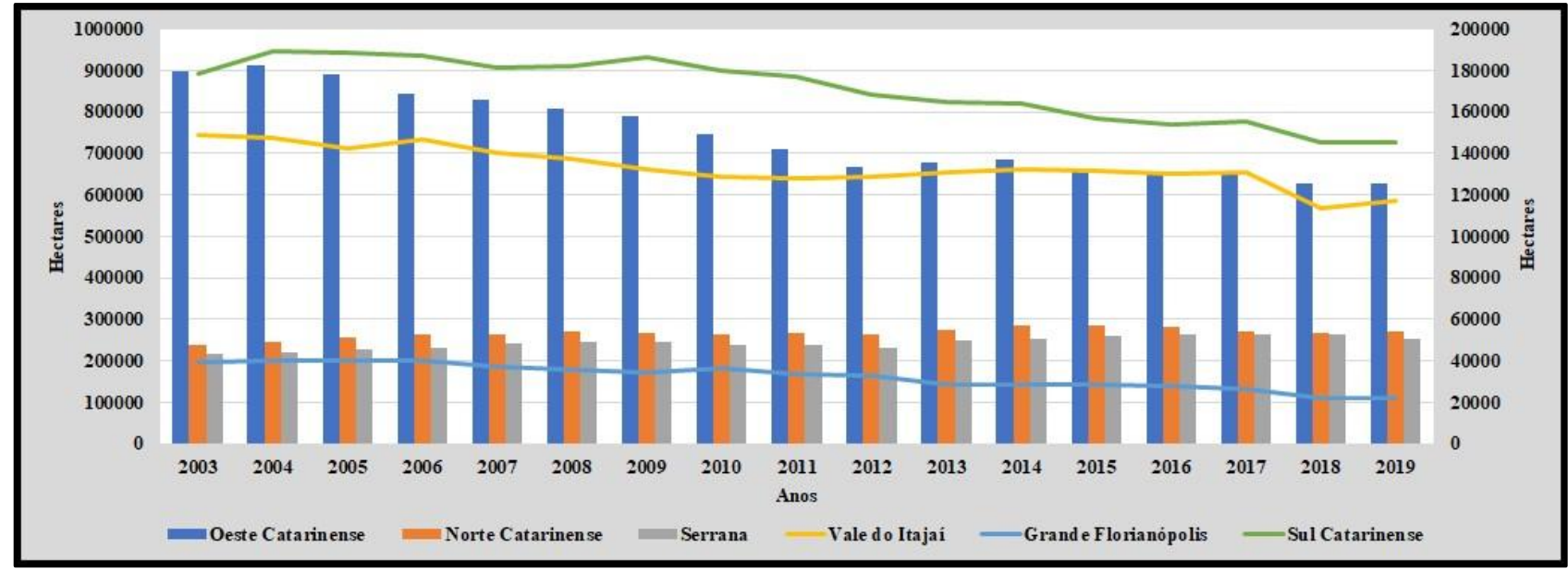

Fonte: IBGE (2021a). Organização: autores

Na variável VAB (Gráfico 3), todas as mesorregiões do estado de Santa Catarina tiveram variação competitiva positiva. A mesorregião Oeste (polarizada pelo município de Chapecó), entre 2003-2019, obteve uma evolução nas receitas de VAB com culturas temporárias de $R \$ 1,39$ bilhão para $R \$ 2,97$ bilhões, representando, em termos percentuais, um acréscimo de 113,6\%. O Norte Catarinense, região do município de Joinville, aumentou o valor em 187\%, na série analisada, saiu de um $\operatorname{VAB}$ de $\mathrm{R} \$ 596,1,4$ milhões para $R \$ 1,71$ bilhão. Essa tendência dinâmica foi escoltada pelas demais mesorregiões, pela ordem decrescente de aferição de VAB no período: Serrana (polarizada pelo município de Lages) cresceu perto de $300 \%$, saindo de $R \$ 343,9$ milhões para atingir $R \$ 1,37$ bilhão; Vale do Itajaí (região do município de Itajaí), cresceu 104,3\%, saiu de receitas na produção agrícola de $\mathrm{R} \$ 553,5$ milhões para $\mathrm{R} \$ 1,13$ bilhão; as mesorregiões

\footnotetext{
${ }^{24}$ Houve uma involução na área plantada das lavouras permanentes na ordem de 3,4\%. No período entre 2003 e 2019, ocorreu competitividade negativa de maior relevância na mesorregião Oeste Catarinense, com $48,9 \%$ de queda. Nas mesorregiões Norte Catarinense, Serrana e Vale do Itajaí, a dinâmica positiva na área cultivada, na ordem, foi de 54\%; 57,4\%; 20\% (IBGE, 2021a).
} 
Grande Florianópolis e Sul (polarizadas pelo município de Criciúma) variaram positivamente, na ordem de $86,9 \%$ e $55,5 \%{ }^{25}$, respectivamente.

Gráfico 3 - Valor adicionado bruto de Produção das lavouras temporárias das mesorregiões de Santa Catarina (mil reais)

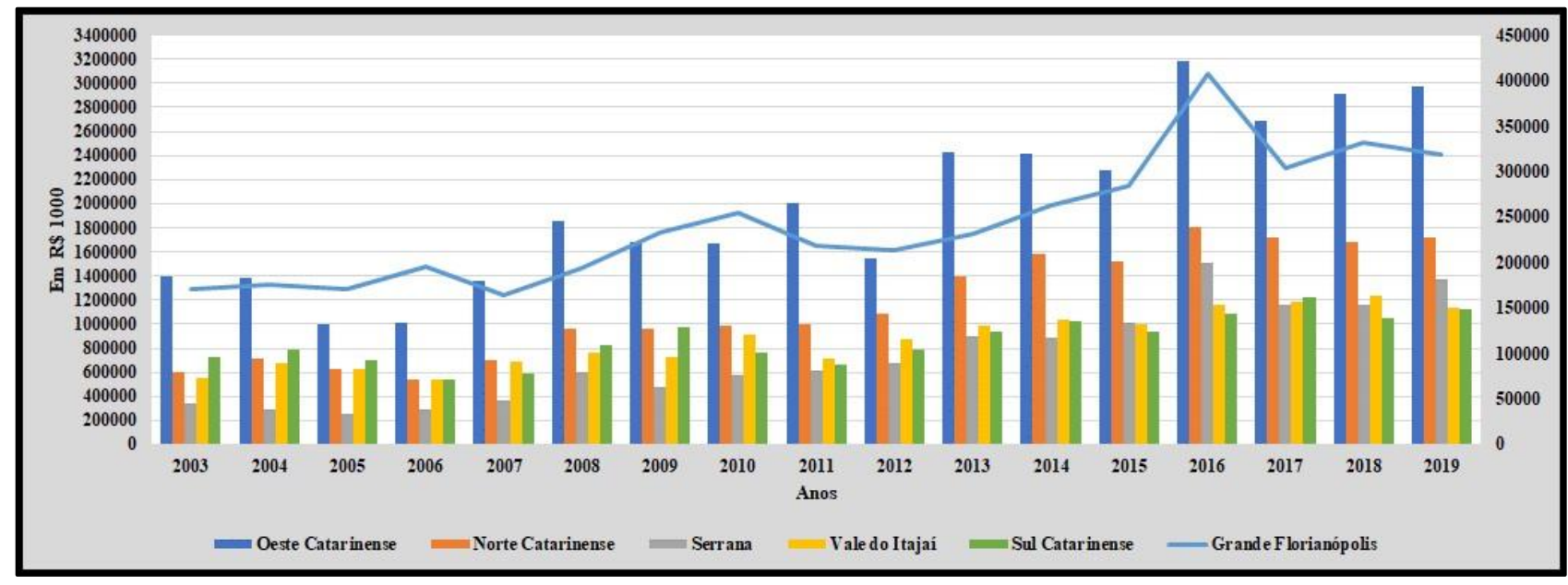

Fonte: IBGE (2021a). Organização dos dados: autores

Essa dinâmica mesorregional do estado de Santa Catarina desenreda-se (Tabela 3), singularmente, devido ao aumento da produção dos bens agrícolas provenientes de lavouras temporárias e permanentes e da silvicultura, com exceção do fumo e do milho. A mesorregião Oeste Catarinense é responsável pelas maiores safras de soja e milho; sozinha é encarregada por 47,1\% (1,07 milhão de toneladas) da produção de soja estadual e 1\% da produção nacional; 56,8\% (1,5 milhão de toneladas) da colheita estadual de milho, 1,5\% da safra nacional; 55,5\% da produção de erva-mate; e 19,1\% da produção estadual de madeira. Em matéria de variação percentual de quantidade produzida, entre 2003-2019, essa mesorregião obteve aumento na soja de $275 \%$. No milho contabilizou queda de

\footnotetext{
25 Santa Catarina aumentou, entre 2003 e 2019, seu VAB nas lavouras permanentes em 203\%, saindo de $R \$ 510,8$ milhões para $R \$ 1,54$ bilhão (IBGE, 2021a). A mesorregião Serrana possui $43 \%$ de todo o VAB do estado nessas lavouras, aumentou de $R \$ 154,3$ milhões para $R \$ 663,4$ milhões, acumulando 330\% no período de 2003 a 2019, sobretudo nas plantações de maçãs, representando 95,2\% do VAB da mesorregião (IBGE, 2021a).
} 
45,8\%, prejuízos competitivos de $61 \%$ na maçã e $20,2 \%$ na madeira, e estagnação produtiva na erva-mate.

Tabela 3 - Quantidade produzida dos produtos agrícolas nas mesorregiões de Santa Catarina (toneladas)

\begin{tabular}{cccccccccc}
\hline $\begin{array}{c}\text { Mesorregiões de } \\
\text { Santa Catarina }\end{array}$ & Arroz & Cebola & Fumo & Maçã & Milho & Soja & $\begin{array}{c}\text { Erva- } \\
\text { mate }\end{array}$ & $\begin{array}{c}\text { Madeira } \\
\mathbf{M}^{3}\end{array}$ \\
\cline { 2 - 10 } & & & & & & & & & \\
\hline Oeste Catarinense & 11046 & 12367 & 44894 & 237731 & 2905938 & 420549 & 48037 & 4147739 \\
Norte Catarinense & 170807 & 2623 & 45098 & - & 570510 & 187089 & 2617 & 4323104 \\
Serrana & 1753 & 23164 & 2967 & 237364 & 446030 & 104401 & 378 & 6547894 \\
Vale do Itajaí & 235186 & 265071 & 55161 & - & 221532 & 136 & 1440 & 504043 \\
Grande Florianópolis & 23022 & 105100 & 6640 & - & 47424 & - & 2 & 11168 \\
Sul Catarinense & 592744 & 1228 & 58579 & - & 119500 & - & - & 185529 \\
\hline & & & & & $\mathbf{2 0 1 9}$ & & & \\
\hline Oeste Catarinense & 76 & 47979 & 18333 & 92926 & 1575063 & 1074396 & 49924 & 3305078 \\
Norte Catarinense & 146364 & 9956 & 72384 & 2342 & 276843 & 526011 & 37340 & 2901665 \\
$\quad$ Serrana & 14 & 40813 & 3405 & 490522 & 544374 & 601014 & 2449 & 9168160 \\
Vale do Itajaín & 202079 & 258679 & 55701 & - & 212756 & 53610 & 196 & 1034825 \\
Grande Florianópolis & 35336 & 99405 & 6969 & - & 33515 & 76 & - & 79677 \\
Sul Catarinense & 678290 & 389 & 35477 & - & 124518 & 15405 & - & 753820 \\
\hline
\end{tabular}

Fonte: IBGE (2021a). Organização dos dados: autores

A Tabela 3 mostra, ainda, que a mesorregião Norte Catarinense passou por variações positivas na produção de erva-mate (1.336\%), saindo de 2,6 mil para 37,3 mil toneladas, o que representa $41,5 \%$ da colheita no estado. Na produção de soja, essa mesorregião apresentou forte impulso dinâmico, crescendo 181,2\%, subindo de 187 mil para 526 mil toneladas. A quantidade produzida nas lavouras de fumo cresceu 60,8\% no período em destaque, pulando de 45 mil para 72,3 mil toneladas, e na produção de cebola cresceu $282,6 \%$. Não obstante, essa mesma mesorregião apresentou taxas negativas na produção de milho $(51,5 \%)$ e de madeira $(32,5 \%)$.

A mesorregião do estado que também apresentou tendência dinâmica na produção de milho e de soja foi a Serrana (Tabela 3). A taxa de crescimento, entre 2003 e 2019, atingiu 22\%, saindo de 446 mil para 544 mil toneladas no milho e, no 
segundo produto, passou de 104 mil para 601 mil toneladas, aumento total de 477\%. Todavia, as maiores participações da mesorregião na produção dos produtos agrícolas catarinenses são na madeira, que passou de 6,5 milhões para 9,1 milhões de m3 - o que totaliza $53,2 \%$ do geral estadual -, e na maçã, com $83,7 \%$ da safra macieira catarinense com mais de 490 mil toneladas em 2019.

Desperta atenção, ainda, na Tabela 3, o índice positivo de 105,3\% na produção de madeira na mesorregião Vale do Itajaí, em que, em 2003, foram colhidos 504 mil m3, e, em 2019, passou para 1,03 milhão de m3. Houve avanço considerável na cultura da soja entre o período em análise, que era quase inexistente e passou de 53,6 mil toneladas. No restante dos produtos, o Vale do Itajaí foi a região que se preservou em estabilidade produtiva.

Seguindo a análise da Tabela 3, a mesorregião Sul Catarinense sempre possuiu propensão a produzir arroz. Em 2003, colheu 592,7 mil toneladas e, em 2019, passou para 678,2 mil, perfazendo um aumento perto de $15 \%$ e conservandose na liderança absoluta do estado, com $63,8 \%$ da colheita arrozeira. Ademais, na mesorregião da Grande Florianópolis, destaca-se, sobretudo, a produção de cebola, uma vez que, mesmo com cristalização produtiva, permaneceu como segunda colocada na produção estadual, com aproximadamente 100 mil toneladas em 2019.

Com base no apresentado, pode-se assinalar que vem ocorrendo no estado de Santa Catarina um processo de reconfiguração regional da produção dos produtos das lavouras e na silvicultura da madeira, caracterizado pelas dinâmicas competitivas de concentração; desconcentração; especialização; disseminação; e exclusão. A soja, o milho e a cebola sofrem desconcentração, especialização e disseminação em todas as regiões. O arroz está em processo de estagnação guiada por uma concentração produtiva na mesorregião Sul. O fumo e a erva-mate estão em movimento de especialização no Norte Catarinense, lastreado em substituição de áreas produtivas. A madeira encontra-se em evolução desconcentrada em direção à região Serrana, e nessa, a maçã está terminantemente concentrada. 
Esses processos vêm definindo um novo espraiamento territorial da agropecuária catarinense e provendo uma especialização produtiva territorial ${ }^{26}$.

Distintivamente das lavouras, na pecuária, como se depreende da Tabela 4, a concentração apresenta-se de forma acentuada no rebanho de bovinos, suínos e frangos. A mesorregião Oeste Catarinense, na criação de bovino, em 2003, detinha 1,4 milhão; em 2019, o número subiu para 2,1 milhões de cabeças, assim, é a região que possui o maior rebanho bovino de Santa Catarina, com 49,5\%. 0 aumento do rebanho bovino catarinense foi não heterogenia entre as demais mesorregiões. Diferentemente do ramo de gado bovino, tanto o suíno como o frango são excessivamente concentrados no Oeste de Santa Catarina. Em 2019, a criação de suíno na região chegou a 76\%, e o rebanho de frango, a $72,7 \%{ }^{27}$.

\footnotetext{
${ }^{26}$ Com referência ainda às lavouras permanentes, não ocorreram alterações significativas na cultura da banana e do pêssego, por razão única do processo territorial do pêssego ter-se concentrado e da banana se especializou em três mesorregiões. Apesar da queda geral na produção do pêssego do estado em 41,6\%, ainda assim, a mesorregião Oeste Catarinense produziu 15,1 mil toneladas em 2019, o que representa $87,6 \%$ do total estadual (IBGE, 2021a). No referente à produção de banana, em que Santa Catarina possui 10,6\% da safra nacional, o Norte Catarinense domina com 52,1\% da produção, seguido por Vale do Itajaí - 35\% e Sul Catarinense - 11,5\% (IBGE, 2021a).

27 Nos suínos, o Sul Catarinense aparece com 9,2\% e o Vale do Itajaí aparece com 8,5\% do total do rebanho no estado em 2019 (IBGE, 2021b). No que diz respeito à criação de frangos, o Sul Catarinense, em 2019, participou com 12,5\% do rebanho (IBGE, 2021b)
} 
Tabela 4 - Rebanho (em cabeças), leite (em mil litros) e vacas ordenhadas (em cabeças) nas mesorregiões de Santa Catarina

\begin{tabular}{cccccc}
\hline Mesorregiões de & \multicolumn{5}{c}{2003} \\
\cline { 2 - 6 } Santa Catarina & Bovino & Suíno & Frango & Leite & Vacas ordenhadas \\
\hline Oeste Catarinense & 1427273 & 4152966 & 104234011 & 909602 & 378570 \\
Norte Catarinense & 250241 & 250723 & 8938369 & 72615 & 35596 \\
Serrana & 672649 & 173351 & 2690204 & 56245 & 51194 \\
Vale do Itajaí & 377392 & 282074 & 12167865 & 162949 & 97772 \\
Grande Florianópolis & 158625 & 36052 & 4239682 & 45405 & 26229 \\
Sul Catarinense & 303645 & 536977 & 13382473 & 85460 & 54059 \\
\hline & & \multicolumn{4}{c}{2019} \\
\hline Oeste Catarinense & 2184528 & 5708196 & 94960129 & 2351848 & 546977 \\
Norte Catarinense & 287859 & 284902 & 8981962 & 96237 & 32192 \\
Serrana & 765529 & 236050 & 3781863 & 101749 & 39074 \\
Vale do Itajaí & 437163 & 649587 & 3567072 & 212305 & 80567 \\
Grande Florianópolis & 211656 & 13349 & 3096655 & 33770 & 23187 \\
Sul Catarinense & 565836 & 698743 & 16293936 & 244271 & 74533 \\
\hline
\end{tabular}

Fonte: IBGE (2021b). Organização dos dados: autores

Isocronicamente aos rebanhos pecuários, o produto derivado da pecuária, o leite, tem a produção bastante concentrada, mas aumentou em todas as mesorregiões, com exceção de na Grande Florianópolis, como mostra a Tabela 4. O Oeste do estado que, em 2003, produzia 909 milhões (68,3\% do total do estado), passou para 2,3 bilhões de litros de leite, em 2019 (77,3\% da produção estadual). Assim sendo, essa concentração da produção de leite se espelha, também, no número de vacas ordenhadas (Tabela 4). Em 2003, a mesma mesorregião Oeste retratava $58,8 \%$ de toda a ordenha do estado; em 2019, a taxa ficou em 68,7\%. Dessa forma, a pecuária catarinense, diferentemente dos produtos das lavouras e silvicultura, encontra-se ainda mais concentrada, especialmente na mesorregião Oeste Catarinense. 


\section{CONSIDERAÇÕES FINAIS}

Demonstrou-se, neste texto, que o processo de ocupação do território catarinense resultou na constituição de duas estruturas produtivas na agricultura. Uma caracterizada pela presença marcante de uma pequena produção mercantil e outra marcada pela presença de propriedades pecuaristas. Contudo, essas duas estruturas, ao longo de sua trajetória evolutiva, sobretudo pós-1960, passaram por profundas transformações, que originaram uma dinamicidade produtiva na agropecuária e sua mundialização.

Argumentou-se que, no período entre 2003-2019, as alterações manifestaram-se na evolução do VBP animal e vegetal. Entretanto, a elevação das rendas geradas contrastou com a queda da área plantada de produtos (feijão, milho, trigo, fumo, entre outros) e a redução das áreas de pastagens. Em contrapartida, ocorreu um aumento da área plantada com soja e madeira (pinus e eucaliptos). A redução da área de pastagens e de lavouras não provocou diminuição da produção total. A redução da produção manifestou-se nas lavouras de feijão e fumo e estabilizou-se na no caso do arroz. Esses aumentos da produção decorreram das boas condições climáticas, preços favoráveis, medidas políticoinstitucionais e pelo aumento da produtividade.

Advogou-se que a produção de carnes vem perdendo participação relativa no conjunto da região Sul do Brasil e nas exportações brasileiras, o que aponta para uma nova divisão territorial do trabalho. Ademais, a despeito de a estrutura produtiva da agropecuária apresentar-se diversificada, constatou-se que vem ocorrendo um novo processo de espraiamento mesorregional da produção agrícola, caracterizado pela concentração/desconcentração, dispersão e exclusão. Esses processos estão acelerando a especialização produtiva territorial. A dispersão se faz, principalmente, no caso da soja em que, em algumas regiões do estado, o incremento anual de área e da produção tem sido significativo, substituindo áreas de pastagens, de milho e de feijão. 
Esse novo processo de espraiamento mesorregional que vem ocorrendo no estado de Santa Catarina, ocorre, sobretudo, nos produtos das lavouras temporárias e permanentes, e na silvicultura, especialmente, a madeira. E esse processo é determinado pelas vantagens dinâmicas competitivas. A soja, o milho e a cebola sofrem desconcentração, especialização; disseminação em todas as mesorregiões. O arroz está em processo de estabilização concentrada na mesorregião Sul Catarinense. O fumo e a erva-mate estão em mobilidade para o Norte Catarinense por meio de movimento de substituição de áreas produtivas, em particular o Oeste. Na mesorregião Serrana, as lavouras de maçã estão em evolução concentrada, e a madeira se desconcentra do Oeste e Norte Catarinenses em caminho forte à concentração na Serra. Entretanto, a pecuária catarinense, em particular dos produtos das lavouras (temporárias e permanentes) e silvicultura, concentrou-se ainda mais, especialmente na mesorregião Oeste.

Dessa maneira, para se ter um grau de entendimento razoável desses processos na agropecuária moderna de escala e escopo, é necessário compreender as especificidades de todos os seus processos produtivos dinâmicos em suas origens e desenvolvimentos. No Brasil, como um país continental, a luminosidade (luz solar), solos e seus nutrientes, temperatura, umidade, relevo, formas de ocupação e de manejo dos territórios são essenciais para entender as estratégias de produção das regiões produtoras, pois essas se diferenciam, e suas necessidades são díspares uma das outras (CUNHA, 2020; ESPÍNDOLA; CUNHA, 2015). A tecnologia, nas últimas décadas, foi um determinante fundamental para o sucesso da agropecuária no país; para os avanços na biotecnologia, genética e, especialmente, para a criação de sementes modificadas. Todavia, as condições naturais constituem, ainda, elemento fundamental da produtividade agrícola e da produtividade do trabalho. Com isso, a combinação entre desenvolvimento tecnológico, evolução econômica e social, e características naturais de cada região 
é basilar para se entender os sistemas de produção agropecuária (CUNHA, 2020; ESPÍNDOLA; CUNHA, 2015).

Por fim, a história não rege o homem, mas sim, o irremediavelmente contrário. A história é apenas a atividade do homem que vai em busca dos fins dele mesmo. Ou seja, não devemos confundir a reprodução da realidade com o processo de construção dessa realidade (CUNHA, 2020). Então, o processo histórico leva em conta as estruturas produtivas, as relações territoriais e sociais e as estruturas espaciais, interação entre o novo e o velho, com domínio do primeiro. Cada momento do processo histórico de desenvolvimento, com sua estrutura econômica, social, política, cultural, dentro de uma formação socioespacial, tem uma significação particular. Por isso, como foi explanado, uma determinada área geográfica "não tem funções permanentes, nem um nível de forças produtivas fixos e relações de produção e de propriedade imutáveis. Interagem e evoluem no processo" (SANTOS, 1977, p. 84). Contudo, as novas estruturas e configurações territoriais não se realizam por completo e não se pode cair em determinismos específicos territoriais, pois não há vocação, o capital transforma-se no tempo e espaço (SANTOS, 1977).

\section{AGRADECIMENTOS}

Ao CNPq pelo financiamento da pesquisa.

\section{REFERÊNCIAS}

BARBOSA, N. Dez anos de Política Econômica. In: SADER, E. (Org.). 10 anos de governos pósneoliberais no Brasil: Lula e Dilma. São Paulo; Rio de Janeiro: Boitempo; Flacso, 2013. p. 63101.

BIELSCHOWSKY, R. Estratégia de Desenvolvimento e as Três Frentes de Expansão no Brasil: um desenho conceitual. Texto para Discussão, Brasília, IPEA, n. 1828, p. 1-27, 2013. 
BRASIL. Ministério da Agricultura, Pecuário e Abastecimento. Valor Bruto da Produção Agropecuária. 2018. Disponível em: http://wnw.agricultura.gov.br/assuntos/politica-agricola/valor-brutoda-producao-agropecuaria-vbp. Acesso em: 25 fev. 2021.

BRASIL. Ministério da Agricultura, Pecuária e Abastecimento. Estatísticas do valor bruto da produção agropecuária. 2021a. Disponível em: http://www.agricultura.gov.br/. Acesso em: 25 fev. 2021.

BRASIL. Ministério da Agricultura, Pecuária e Abastecimento. Estatísticas de comércio exterior do agronegócio brasileiro. 2021b. Disponível em: http://sistemasweb.agricultura.gov.br/pages/AGROSTAT.html. Acesso em: 27 fev. 2021.

CONTINI, E. et al. Evolução recente e tendências do agronegócio. Revista de Política Agrícola, Brasília, CONAB, ano XV, n. 1, jan.-fev.-mar, p. 5-28, 2006.

CHOLLEY, A. Observações sobre alguns pontos de vista geográficos. Boletim Geográfico, Rio de Janeiro, n. 180, p. 267-276, 1964.

CUNHA, R. C. C. A geoeconomia da cadeia produtiva da soja no Brasil. 2020. 313 f. Tese (Doutorado)- Curso de Geografia, Geociências, Universidade de Federal de Santa Catarina, Florianópolis, 2020.

CUNHA, R. C. C.; CRUZ, W. L. de M. Aspectos geoeconômicos da cadeia produtiva da Soja no Estado de Santa Catarina: Produção e Circulação. Geo UERJ, Rio de Janeiro, n. 31, p. 745-769, 2017.

CUNHA, R. C. C.; ESPÍNDOLA, C. J. Dimensão dinâmica do processo produtivo e territorial da agropecuária no Rio Grande do Sul pós-2003. Revista da Anpege, São Paulo, v. 16, n. 30, p. 7599, 2020.

CUNHA, R. C. C.; FARIAS, F. R. Dinâmica produtiva e ordenamento territorial dos agronegócios do Mato Grosso do Sul pós-2003. Geosul, Florianópolis, v. 34, n. 71, p.130-153, 2019.

EPAGRI/CEPA. Instituto de Planejamento e Economia Agrícola de Santa Catarina. Síntese Anual da Agricultura Catarinense. 2004. Disponível em: http://www.epagri.sc.gov.br/?page_id=3210. Acesso: 9 mar. 2021.

EPAGRI/CEPA. Instituto de Planejamento e Economia Agrícola de Santa Catarina. Síntese Anual da Agricultura Catarinense. 2009. Disponível em: http://www.epagri.sc.gov.br/?page_id=3210. Acesso: 10 mar. 2021.

EPAGRI/CEPA. Instituto de Planejamento e Economia Agrícola de Santa Catarina. Síntese Anual da Agricultura Catarinense. 2017. Disponível em: http://www.epagri.sc.gov.br/?page_id=3210. Acesso: 7 mar. 2021. 
EPAGRI/CEPA. Instituto de Planejamento e Economia Agrícola de Santa Catarina. Síntese Anual da Agricultura Catarinense. 2020. Disponível em: http://www.epagri.sc.gov.br/?page_id=3210. Acesso: 5 mar. 2021.

ESPÍNDOLA, C. J. A dispersão territorial dos investimentos do agronegócio de carne. Anais de Geografia Econômica e Social, Florianópolis, v. 2, p. 251-281, 2009. Disponível em: http://cadernosgeograficos.ufsc.br/aquisicao/revista-geografia-economica/. Acesso em: 26 fev. 2021.

ESPÍNDOLA, C. J. As duas macroformações socioespaciais do Sul do Brasil na gênese da indústria de carnes. Ensaios FEE, Porto Alegre, v. 37, p. 715-738, 2016a. Disponível em: https://revistas.fee.tche.br/index.php/ensaios/article/viewFile/3419/3792. Acesso em: 25. fev.2021.

ESPÍNDOLA, C. J. Ciclo de crescimento da economia brasileira e desempenho do agronegócio catarinense. Geografia (Londrina), Londrina, v. 25, p. 91-109, 2016b. Disponível em: http://www.uel.br/revistas/uel/index.php/geografia/article/viewFile/24919/20546. Acesso em: 27. fev. 2021.

ESPÍNDOLA, C. J. A dinâmica geoeconômica do agronegócio brasileiro de carnes e soja. In: LAMOSO, L. P. (Org.). Temas do desenvolvimento econômico brasileiro e suas articulações com o Mato Grosso do Sul. Curitiba: Íthala, 2016c, p. 19-53.

ESPÍNDOLA, C. J.; CUNHA, R. C. C. A dinâmica geoeconômica recente da cadeia produtiva de soja no Brasil e no Mundo. Geotextos, v. 11, n. 1, p. 217-238, Salvador, UFBA, 2015.

ESPÍNDOLA, C. J.; CUNHA, R. C. C. Os agronegócios no desenvolvimento econômico brasileiro. In. ALMADA, J., PAULA, L. F. de; JABBOUR, E. M. K. (Orgs). Repensar o Brasil. Rio de Janeiro: AMFG, 2020, p. 371-402.

ESPÍRITO SANTO, E. Agricultura no Estado de Santa Catarina, Período 1920-1985. Estudos Econômicos, São Paulo v. 28, n. 3, jul-set, p. 453-473, 1998.

FARIA, L. A. E. Sobre o conceito de valor agregado: uma interpretação. Ensaios FEE, Porto Alegre, v.3, n.2, p. 109-118,1983.

GIL, A. C. Métodos e técnicas de pesquisa social. Atlas: São Paulo, 1994.

GONÇALVES, J. S. Agricultura sob a égide do capital financeiro: passo rumo ao aprofundamento do desenvolvimento dos agronegócios. Informações econômicas, São Paulo, IEA, v. 35, p. 736, abr. 2005.

GONÇALVES, R. Crise econômica: Radiografia e soluções para o Brasil. 2008. Disponível em: http://www.ie.ufrj.br/oldroot/hpp/intranet/pdfs/crise_economica_radiografia_e_solucoes_para _o_brasil_29_outubro_2008.pdf. Acesso em: 23 fev. 2021. 
IBGE. Instituto Brasileiro de Geografia e Estatística. Divisão regional do Brasil em mesorregiões e microrregiões geográficas. Rio de Janeiro, v. 1 2012. Disponível em: https://www.ibge.gov.br/geociencias/organizacao-do-territorio/divisao-regional/15778divisoes-regionais-do-brasil.html?=\&t=o-que-e. Acesso em: 10 mar. 2021.

IBGE. Instituto Brasileiro de Geografia e Estatística. Pesquisa Agrícola Municipal. Rio de Janeiro, 2021a. Disponível em: https://sidra.ibge.gov.br/home/pimpfbr/brasil. Acesso em: 26 fev. 2021.

IBGE. Instituto Brasileiro de Geografia e Estatística. Pesquisa Pecuária Municipal. Rio de Janeiro, 2021b. Disponível em: https://sidra.ibge.gov.br/home/pimpfbr/brasil. Acesso em: 26 fev. 2021.

IBGE. Instituto Brasileiro de Geografia e Estatística. Produção da extração vegetal e a silvicultura. Rio de Janeiro, 2021c. Disponível em: https://sidra.ibge.gov.br/home/pimpfbr/brasil. Acesso em: 23 fev. 2021

IBGE. Instituto Brasileiro de Geografia e Estatística. Pesquisa Trimestral de abate. Rio de Janeiro, 2021d. Disponível em: https://sidra.ibge.gov.br/home/pimpfbr/brasil. Acesso em: 23 fev. 2021

KLEIN, H. S.; LUNA, F. V. Alimentando o mundo: o surgimento da moderna economia agrícola no Brasil. São Paulo: FGV Editora, 2020.

MAMIGONIAN, A. Estudo Geográfico das Indústrias de Blumenau. Revista Brasileira de Geografia, n. 3, p. 389-480, Rio de Janeiro: IBGE. 1966.

MAMIGONIAN, A. As conquistas marítimas portuguesas e a incorporação do litoral de Santa Catarina. In: ANDRADE, M. C.; FERNANDES, E. M.; CAVALCANTI, S. M. (Orgs.). O mundo que o português criou: Brasil: século XVI. Recife: CNPq/FJN, 1999. P. 57-78.

MAMIGONIAN, A. Tese de livre docência. São Paulo, USP, 2005. Disponível em: https://teses.usp.br/index.php?option=com_jumi\&fileid=13\&ltemid=78\&lang=pt-br. Acesso em: 28 fev. 2021

MARCONDES, T Agropecuária em Santa Catarina: Cenário atual e principais tendências. Revista NECAT, ano 5, n. 9, p. 8-38, 2016.

NEUMANN, E, FAJARDO, S., MARIN, M. Z. Transformações recentes no espaço rural brasileiro: análises do papel do Estado nas políticas públicas de desenvolvimento rural nas décadas de 1970 a 1990. RAEGA, Curitiba, v. 40, p. 177-194, 2017.

PADILHA, W.; ESPÍNDOLA, C. J. Prodecoop e Procap-agro e o crescimento das cooperativas agroindustriais da região sul. In: ENANPEGE, 11., 2015, Presidente Prudente. Anais... . Presidente Prudente: Edufgd, 2015. v. 1, p. 6187- 6198. 
PELUSO JR, V. Aspectos Geográficos de Santa Catarina. Florianópolis: FCC/EDUFSC, 1991.

SANTOS, M. Sociedade e espaço: A formação social como teoria e como método. Boletim Paulista de Geografia, São Paulo, v. 54, p. 81-100, jun. 1977.

SOUTO MAIOR, A. S. Povoamento. In. CATALDO, D. M. (Org.). Geografia do Brasil: A Grande região Sul. Rio de Janeiro: FIBGE. v. 4, n. 2, p. 3-46, 1968.

SOUZA, J. J. de. O complexo de laticínios no Brasil: o caso da região Sul. 2014. 289 f. Tese (Doutorado) - Curso de Geografia, Universidade Federal de Santa Catarina, Florianópolis, 2014.

WAIBEL, L. Princípios da Colonização Européia no Sul do Brasil. Revista Brasileira de Geografia, Rio de Janeiro, ano 50, número especial, IBGE, 1988.

\section{1 - Roberto César Costa Cunha:}

Geógrafo (UFMA), Doutor em Geografia (UFSC). Pesquisador nível de pós doutorado DEGEO UFSC. Bolsista do CNPq., https://orcid.org/0000-0002-6190-6186•robertoujsma@hotmail.com Contribuição: projeto; pesquisa; elaboração; análise e escrita.

\section{2 - Carlos José Espíndola:}

Geógrafo (UFSC), Doutor em Geografia (USP), Professor Titular do DEGEO UFSC, Bolsista produtividade do CNPq., https://orcid.org/0000-0002-5857-6067•carlos.espindola@ufsc.br Contribuição: projeto; pesquisa; elaboração; análise e escrita.

\section{Como citar este artigo}

CUNHA, R. C. C.; ESPÍNDOLA, C. J. Eficiência produtiva da agropecuária do estado de Santa Catarina e seu novo espraiamento territorial pós-2003. Geografia Ensino \& Pesquisa, Santa Maria, v. 25, e38, p. 1-35, 2021. DOI 10.5902/2236499464708. Disponível em: https://doi.org/10.5902/2236499464708. Acesso em: dia mês abreviado. ano. 